\title{
Synthesis Of 2-(1, 3- Dihydro- 3 - Oxo- 2h - Pyridylpyrr- 2- Ylidene)-1, 2-Dihydro- 3h- Pyridylpyrrol- 3- One.
}

\author{
*Nwokonkwo, D.C. \\ Faculty Of Physical Sciences, Department Of Industrial Chemistry Ebonyi State University Abakaliki \\ Nigeria.
}

\begin{abstract}
Synthesis of 2-(1,3-dihydro- 3 - oxo- 2H - pyridylpyrr- 2- ylidene)-1, 2-dihydro-3H-pyridylpyrrol3- one, polycyclic bi-indolinedione vat dye was carried out using a heterocyclic compound, 2-aminopyridine, chlorinated ethanoic acid and sodium hydroxide. The aromatic glycine that resulted as an intermediate to this new polycyclic bi-indolinedione compound was fused with admixture sodamide: sodium hydroxide: potassium hydroxide and oxidized by acidified concentrated solution of ferric chloride using hydrochloric acid. This dye showed good fastness properties on cotton, polyester, dacron, silk, wool and paper. The spectral analysis was in agreement with the proposed structure of the compound. UV: (DMSO) גmax nm; 609. IR:(KBr) $v \mathrm{~cm}^{-1} ; 3402$, 2251.66, 2078.00, 1650.25, 1398.18, 1005.50 825.37, 764.03, 627.00. ${ }^{1} \mathrm{H}-\mathrm{NMR}$ :( DMSO-d 6 ) 8ppm; 6.6, 7.2,

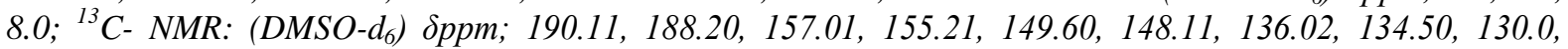
128.94, 27.53, 126.31, 124.30, 123.91. MS: $\mathrm{m} / \mathrm{z} ; 32,77,105,181,264(M+)$.
\end{abstract}

Keywords: fused, heterocyclic, oxidized, spectral analysis, vat dye

\section{Introduction}

Dyes are intensely coloured substances which when applied to a substrate, imparts colour to it by a process which at least temporarily, destroys any crystal structure of the coloured substance [1-2]. The process of imparting colour to a substance is called dyeing, these dyes are retained in the substrate by absorption, solution and mechanical retention or by ionic, covalent, and hydrogen bonding. In other words, dyes are those coloured compounds that can be fixed on fabrics by chemical or physical bonding.

Vat dyes are made of organic colouring matter, which is capable of undergoing a reversible reductionoxidation cycle without serious colour loss or change in shade. They are applied to fibres, using open vats from where they derived their name. They are usually insoluble in water, but are solubilized by conversion to a soluble product, known as leuco-form by treating the dyes with reducing agents and alkali, which are afterwards insolubilized after they have been absorbed by the fiber and exposed to air. The most common vat dye is indigo or Vat Blue synthesized from anthranilic acid or aniline, which are homocyclic aromatic ring systems as well as their substituted analogues [3-11].

Reduction of indigo gives indigo white, which is not exactly white but yellow or brown, this compound is insoluble in water but reacts with sodium hydroxide to form water-soluble sodium derivative of the dye. Other examples of vat dyes include Vat Blue 14, Disodium 2, 11-disulpho -4, 13- dihydroxydibenzo [C, N] triphenodithiazine-8, 17-dione and 6-chlorobenzo [a] -azaphenoxazin-5-one. [14-15]. Dyes are primarily used in most of the local industries to impart desirable colours. Such industries include textiles, paint, food, paper, cosmetics, ink, petroleum etc. Dyes are also used as drugs, indicators and sensitizers in photographic films [1629].

This article is reporting the first synthesis of a heterocyclic indigo dye; 2-(1, 3- dihydro- 3 - oxo- $2 \mathrm{H}$ pyridylpyrr-2- ylidene)-1, 2-dihydro- $3 \mathrm{H}$ - pyridylpyrrol-3-one.

\section{General Experimental Procedure}

\section{Experimental}

All reagents were of analytical grades and were purchased from Aldrich Chemical Company Incooperation Milwaukee USA. All melting points were determined on Gallenkamp apparatus model 630 and Electrothermal Digital melting point apparatus using open capillary tubes and were uncorrected. All weighing was done on Mettler P2010 and AE 166 digital balances. Thin-layer chromatography was performed on plates precoated with silica gel: Kieselgel $60 \mathrm{~F}_{254-366}$ (E.Merck) (obtained from Alltech, Avondale, PA) and visualized by spraying with $50 \% \mathrm{H}_{2} \mathrm{SO}_{4}$ or iodine vapour; column chromatography was run on neutral alumina; this was used as a purification procedure. The infrared spectra were recorded on a Perkin-Elmer model 337 grating infracord spectrophotometer as $\mathrm{KBr}$ discs or as a solution using deuterated Dimethylsulphoxide (DMSO) at Central Research Laboratory University of Ibadan, Nigeria. Nuclear magnetic resonance spectra $\left({ }^{1} \mathrm{H}-\mathrm{NMR}\right.$ and ${ }^{13} \mathrm{C}$-NMR) were determined on Fourier Transform (FT) model 6853 in deuterated dimethylsulphoxide at ambient temperature using Trimethylsilane (TMS) as internal standard unless otherwise stated. At high field 
region the signals due to the solvents such as deuterated dimethylsulphoxide (DMSO), water etc showed up at $\delta$ 3.50-1.25 in the some of the spectra. The synthesized compounds were recrystallized from dimethylsulphoxide and / or washed with dilute hydrochloric acid where possible. The chemical shifts were reported on the delta scale $(\delta)$ in parts per million. The NMR was carried out at Central Science Laboratory Obafemi Awolowo University of Ile-Ife, Nigeria. Ultraviolet/Visible spectroscopy was recorded on UVI spectrophotometer model 061408 using distilled water and deuterated Dimethylsulphoxide in $1 \mathrm{~cm}$ quartz cells. The absorption maximas were given in nanometers $(\mathrm{nm})$. The Infrared spectra were done at Central Science Laboratory Obafemi Awolowo University Ile-Ife, Nigeria. The mass spectra were determined on GC-6890N coupled with MS-5973N at Central Science Laboratory Usman Danfodio University Sokoto, Nigeria.

All preparations were monitored by thin layer chromatography (T.L.C) All intermediate products were purified by column chromatography on aluminum oxide 90 (Merck, 70-230 mesh ASTM) using acetone, methanol, water, dimethylsulphoxide and normal Butanol - glacial acetic acid - water solvent system (nBuOH AA- $\mathrm{H}_{2} \mathrm{O}$ 5:1:4) as eluting solvents.

\section{Glycine From 2-Aminopyridine}

Into a $1000 \mathrm{ml}$, capacity round bottomed flask was introduced $200 \mathrm{ml}$ Nitrobenzene. To this solvent was added 2-aminopyridine (64g, $0.42 \mathrm{~mole})$ sodium hydroxide pellets $(20 \mathrm{~g}, 0.5 \mathrm{~mole})$ and monochloroacetic acid $(39.69 \mathrm{~g}, 0.42 \mathrm{~mole})$ in small portions. The mixture was heated with stirring on a stirrer heater and refluxed at a temperature between $300-320^{\circ} \mathrm{C}$ for 6 hours.

Warning! The addition of monochloroacetic acid should be done with caution because of the evolution of hydrochloric acid fumes, which is very violent.

The reaction was monitored by TLC using n-BuOH-AA- $\mathrm{H}_{2} \mathrm{O}(5: 1: 4)$ solvent mixture as mobile phase. At the end of refluxing period, nitrobenzene was removed from the dark slurry that formed by decantation and the dark mass washed repeatedly with portions of $200 \mathrm{ml}$ acetone to yield a dark brown gummy compound. This was dissolved in methanol and passed through a column packed with alumina. The eluant was collected, treated with activated charcoal, filtered, the solvent was removed by distillation to reveal $32.0 \mathrm{~g}$ of the glycine as light brown powder, melting point $179^{\circ} \mathrm{C}$ (decomposition).

The UV: $\left(\mathrm{H}_{2} \mathrm{O}-\mathrm{d}_{6}\right)(\mathrm{nm}) \lambda \min 253, \lambda \max 368$; IR: $(\mathrm{KBr}) \cup \max \left(\mathrm{cm}^{-1}\right) 3322(\mathrm{OH}$ of $\mathrm{COOH})$, 3160 ( $\mathrm{NH}$ of amine), 2920, 2036( $\mathrm{C}=\mathrm{C}$ of aromatics), 1664 ( $\mathrm{C}=\mathrm{O}$ of carbonyl ),1481, 1386, 1233, 1168, 1089, 987, 883, 766. ${ }^{1} \mathrm{H}-\mathrm{nmr}\left(\mathrm{DMSO}_{-} \mathrm{d}_{6}\right) \delta \mathrm{ppm} 6.8-8.2(\mathrm{~m}$, aromatic Hs), $\delta 5.0(\mathrm{br}), \delta 11.0(1 \mathrm{H}, \mathrm{s}) \delta 4.0(\mathrm{t}$ $\left.\mathrm{CH}_{2}\right) ;{ }^{13} \mathrm{C}-\mathrm{nmr}\left(\mathrm{DMSO}-\mathrm{d}_{6}\right) \delta 174(\mathrm{COOH}), 155.5,137.9,130.3,112.9$ (arom.), $68.5\left(\mathrm{CH}_{2}\right.$-aliph.); MS: m/z 152 $(100 \%)$.

2-(1, 3- DIHYDRO- 3 - OXO- 2H - PYRIDYLPYRR- 2-YLIDENE)-1, 2-

\section{Dihydro- 3h- Pyridylpyrrol- 3- One.}

This was prepared by fusion of $(8.74 \mathrm{~g}, 0.068 \mathrm{~mole})$ of the glycine with $(43.70 \mathrm{~g}, 0.15 \mathrm{~mole})$ potassium hydroxide, $(43.70 \mathrm{~g}, 0.15 \mathrm{~mole})$ sodium hydroxide and $(8.74 \mathrm{~g}, 0.2$ mole) sodamide. These were ground intimately, introduced into a $1000 \mathrm{ml}$ Pyrex conical flask, to this mixture was added $100 \mathrm{ml}$ nitrobenzene and gently heated. As the temperature was gradually and cautiously increased, the colourless mixture gradually changed to deep orange colour with corresponding change in the state of the mixture; from solid to liquid with evolution of steam. At a temperature of $220^{\circ} \mathrm{C}$, the liquid mixture fused. This process was accompanied by vigorous evolution of white fumes and the odour of ammonia was evident, this took about 120 mins. On cooling, the mixture was dissolved in $200 \mathrm{ml}$ distilled water and passed through a column packed with neutral alumina wetted with water. The eluant was treated with ferric chloride solution to give a dirty brown precipitate or coagulant, which on addition of concentrated hydrochloric acid, changed to dark-green then dark- blue precipitate. This was filtered, washed with six portions of $50 \mathrm{ml}$ concentrated hydrochloric acid and air-dried to give $10.64 \mathrm{~g},(67.2 \%)$ dark-blue coloured compound which decomposition at a temperature between 390 $393^{\circ} \mathrm{C}$.

UV-VIS: $\lambda$ max $\left(\mathrm{H}_{2} \mathrm{O}-\mathrm{d}_{6}\right) 732 \mathrm{~nm}$.IR: $(\mathrm{KBr}) \cup \max \left(\mathrm{cm}^{-1}\right) 3404$ (b, N-H), 2251 (s, methines), 2078, 1650 $(\mathrm{C}=\mathrm{O}), 1398,1005,825,764,627.1 \mathrm{H}-\mathrm{NMR}$ : $\left(\mathrm{DMSO}_{-} \mathrm{d}_{6}\right), \delta 4.0$ (d), 6.99, 7.36, 8.50 ( arom. Hs). ${ }^{13} \mathrm{C}-\mathrm{NMR}$ : $\left(\mathrm{DMSO}_{6}\right) \delta 192$ (d, C=O), 155.9 (d, q) 149 (d), 136.4 (d), 128.0 (d, q), 127.1 (d, C=C), 124.5 (d). MS: m/z $264(100 \%)$. Anal.cald. f or $\mathrm{C}_{14} \mathrm{H}_{8} \mathrm{~N}_{4} \mathrm{O}_{2}: \mathrm{C}, 63.63 ; \mathrm{H}, 3.03 ; \mathrm{N}, 21.2 ; \mathrm{O}, 12.1$.

\section{Fastness Property}

The colourfastness of this compound was carried out on textiles; polyester, cotton, silk, dacron and wool, it showed good fastness property.It was also fast on paper. 


\section{Results And Discussion}

Glycine (1) was synthesized from 2-aminopyridine by treating the substrate with monochloroacetic acid and sodium hydroxide at reflux temperature. Microanalysis is in agreement with the assigned structure. The recovered glycine was treated in a second step by reacting it with sodamide, potassium hydroxide and sodium hydroxide to give an intermediate (2) and subsequently to (3) : 2-(1, 3- dihydro- 3 - oxo- $2 \mathrm{H}$ - pyridylpyrr-2ylidene)-1, 2-dihydro- 3H- pyridylpyrrol-3-one [30-31]. The oxidation to (3) was achieved by treating (2) with ferric chloride and concentrated hydrochloric acid; this was because of the observation of the slow rate of oxidation when (2) was exposed to air oxidation by mechanical agitation compared to the rate of oxidation using ferric chloride / concentrated hydrochloric acid even without air. Elemental analysis was in agreement with the formular $\mathrm{C}_{14} \mathrm{H}_{8} \mathrm{~N}_{4} \mathrm{O}_{2}$. The infrared spectrum at 3402 (two bands) were in agreement $\mathrm{N}-\mathrm{H}$ band of pyridine. The shift from $368 \mathrm{~nm}$ of the glycine to $612 \mathrm{~nm}$ yellow region is in agreement with indigo dyes [32-34] having an extended conjugative system. Confirmatory evidence for the assigned structure 3 was provided by mass spectrum which showed a molecular peak / base peak at m/z $264(100 \%)$ for $\mathrm{C}_{14} \mathrm{H}_{8} \mathrm{~N}_{4} \mathrm{O}_{2}$. Compound 3, is, therefore a new polycyclic bi-indolinedione dye of heterocyclic ring system. Its production from compound 1 proceeds by a nucleophilic attack by the $\mathrm{NH}_{2}$ group of sodamide to form an imine A which progressed through several reaction pathways with intramolecular cyclization, compound $\mathrm{B}$, hydrolysis to yield compound $\mathrm{C}$, dimerization to $\mathrm{D}$, tautomerism to $\mathrm{E}$ and reduction to $\mathrm{F}$, this is shown in schemes 1 and 2 . This compound was readily reduced by refluxing with sodium hydrosulphite to give a dihydro product which was easily oxidized by atmospheric oxygen to the starting material. This property is common to all vat dyes.

\section{Conclusion:}

The compound 2-(1, 3- dihydro- 3 - oxo- $2 \mathrm{H}$ - pyridylpyrr-2- ylidene)-1, 2-dihydro- $3 \mathrm{H}$ - pyridylpyrrol3 -one is a new dark-blue colourant applicable as vat dye to textile materials and also as a pigment. Good fastness to washing, light, basic and acidic solutions makes it a valuable commercial vat dye. REFERENCES

Keith M .B, Organic Chemistry, Englewood Clifts N.F. Prentice Hall Inc, USA 1961.

Reichel T and Balint A, Acad. Rep. Populare Romine Studii Cercetari Chem, 9, 1961, 521.

David $\mathrm{H}$ and Rembert $\mathrm{J}$, The Indigo of Commerce in

Colonial North America, Econ. Botany 33 (2), 1979, 128-134..

Golding Bt. and Pierpoint C, Indigo Blue $E d$.

Chem, 1986, 71-73.

Graham, D. Colour and Chemical Constitution of Dyes, Am. Chem. Soc, Monograph Series, Krieger Pub. Co, New York 1972, 663.

Rowe, F.M. The Development of the Chemistry of Commercial Synthetic Dyes. Instr. Chem, London pp. 1671938,189.

Rys P and Zollinger H, Fundamentals of Chemistry and Applications of Dyes, Wiley Interscience, London, 1972, 124.

Sachs F and Kempf R,.Uber p-Halogen-o-Nitrobenzaldehyde. Ber. Dtsch. Chem. Ges, 1903, 36

Serrano A.L. and Roos B.O, The Theoritical Study of Indigoid Dyes and Their Chromophore. Eur. J. of Chem, 3, (5), 1996, 717-725.

Sharma B.R, Industrial Chemistry Including Chemical Engineering, $15^{\mathrm{TH}}$. Ed. Geol Publishing House Meerut Prentice Hall Inc, USA, 2006.

Withnall R, Clark R.J.H and Cooksey DanielsNon- Destructive In Situ Identification of Indigo/Woad and Shellfish Purple By Raman Spectroscopy and Visible ReflectanceSpectroscopy, Dyers Hist of Arch, 11,

1993,19-24.

Posner, T, Beitrage Zurkenntuis Der Indigo-Gruppe VI Uber Die Einwirkung von Saure-Chloriden auf Indigo und Indigo-Derivative, Ber.Dtsch.Chem, 59, 1926,799-1833

Von Eller H, Stereochem De l'Indigo dans l'etat Cristallin, C.R.Hebd. Seances, Acad. Sci .239, 1954, 975976 .

Fierz-David H.E and Blangey L, Fundamental Processes of DyeChemistry, Interscience New York, 1949.

Okafor C.O, Okerulu I.O and Okeke S.I Vat Dyes from Three New Heterocyclic Ring System and Pigments, Elsevier Applied Science Publishers Ltd. England, 8, 1987.

Okafor C.O, Studies in the Heterocyclic Series viii, The First Synthesis of a Triazaphenothiazine Ring, J.Org. Chem, 38(26) 1973, 4387-4390.

Okafor, C.O, Steenberg, M. L. and Buckley, J.P, A New Triazaphenothiazine Ring with Tranquilizing Activity, Het. Chem, 12, 1975, 813.

Okafor, C.O, Studies in the Heterocyclic Series xvii, A new Type of Triazaphenothiazine, J. Het.Chem, 17, 1980, 149.

Okafor, C.O, Studies in the Heterocyclic Series xvi. Open Azaphenothiazine as New Central Nervous System Depressants. Chem. Pharm 30 ( I), 1982, 302-318. 
Amaral L. and Kristiansen J.E, Phenothiazine; Potential Management of Creutzfeldt-Jacob Disease ant its Variants, Int. J. Antimicro Agents. 18, 2001, 411-417.

Amaral L, Martins M. and Viveiros M. Enhanced killing of intracellular multidrug- resistant Mycobacterium tuberculosis by compounds that affect the activity of efflux pumps. J. antimicro. Chemother, 59, 2007,12371246.

22. Barbieri F, Alama A, Tasso B, Boido V, Bruzdo C and Sparatore F, Quinolizinyl Derivatives Of Imminobenzyl And Phenothiazine As Multidrug Resistance Modulators In Ovarian Cancer Cells. Invest. New Drugs, 21, 2003, 413-420.

23 Gupta R.R and Kumar M, Synthesis, Properties And Reactions Of Phenothiazines, In Phenthiazines and 1,4-Benzothiazines- Chemical and Biological Aspects. Ed. Gupt, Rr Elsevier, Amsterdam, 1988, 1-161.

24. Khatri V; Sareen V, Sharma K, Singh P and Sareen S, Synthesis and Biological Evaluation of Substituted 10H-1-Azaphenothiazine And Their 5-Oxide Derivative, 1 (4), 2011, 305-310.

25. Krystain P. Margozata J, Beata M, Micha Z, Jolanta A and maja K, Anticancer Activity of Newly Synthesized Azaphenothiazines from NCI's Anticancer Screening Bank, Institute Of Pharmacology, Polish Academy of Science, 62, 2010, 319-332.

26. Mayur Y.C, Jagadeesh S and Thimmaiah K.N, Targeting calmdulin In Reversing Multidrug Resistance In Cancer Cells, Mini Review (Rev) Medicinal Chem,6. 2006,1383-1389.

27. Molnar A, Amaral L and Molnar J, Antiplasmid Effect of promethazine In Mixed Bacterial Cultures, Int. J. Antimicrob. Agents, 22. 2003, 17-222.

28. Mosnaim A. D; Ranade V.V, Wolf M.E, Puente J, and Valenzuela M.A, Phenothiazine molecule provides the Basic Chemical Structure for various Classes of Pharmacotherapeutic Agents. Amer. J. Therap, 13. 2006, 261-273.

29. Motohashi N. and Gupta R.RPhenothiazines And 1,4-Benzothiazines: Chemical and Biomedical Aspects .Elsevier, Amsterdam, 1998, 705-774.

30 Lubs H.A, The Chemistry of Synthetic Dyes and Pigments, Roberts E. Krieger Publishing Co, 1972, 5.

31 Bahl, B.S; Advanced Organic Chemistry, S. Chard Pub.Co, Ltd, New Delhi 1155-1156 (2007).

32 Serrano A.L and Roos B.O, The Theoretical Study of Indigoid Dyes and Their Chromophore. Eur. J. Chem, 3, (5), 19967, 17-725.

33. Traftefand H.R, Theory and Application of Ultraviolet Spectroscopy, John Wiley and Sons Inc, New York, $1962,187$.

34. Othmer K, Encyclopeadia of Chemical Technology. $2^{\text {nd }}$. Ed. 7. Interscience New York, 1965, 462.

-(1, 3- dihydro- 3 - oxo- $2 \mathrm{H}$ - pyridylpyrr-2- ylidene)-1, 2-dihydro-3H-pyridylpyrrol-3-one is synthesized from pyridylpyrrol-3-one using $3 \mathrm{M}$ ferric chloride solution and concentrated hydrochloric acid. Pyridylpyrrol3-one was prepared from 2-aminopyridine in a substitution nucleophilic bimolecular $\left(S_{N} 2\right)$ with chloroacetic acid. High boiling organic solvent; nitrobenzene was used at a temperature of $300^{\circ} \mathrm{C}$. An isolable intermediate compound, 2-pyridylglycine that resulted from the reaction of 2-aminopyridine melted between $179-180^{\circ} \mathrm{C}$ and

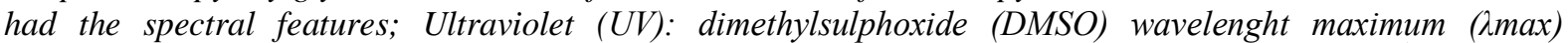
nanometers $(\mathrm{nm}) ; 338,398,460$. Infrared (IR): wave number maximum (vmax) per centimeter $\left(\mathrm{cm}^{-1}\right) ; 3786.18$, 3322.00 3160.10, 2920.712036.82. 1664.28, 1613.56, 1481.691386.61. Proton nuclear magnetic resonance $\left({ }^{1} H\right.$ NMR): Deuterated dimethylsulphoxide $\left(D M S O-d_{6}\right)$ delta $(\delta)$ parts per million (ppm); 3.84.0, 5.2, 6.8, 7.0, 7.6, 7.8.Carbon-13 $\left({ }^{13} \mathrm{C}-\mathrm{NMR}\right)$ : (DMSO-d $) \delta \mathrm{ppm} ; 174.77,144.56,143.17,137.83,130.31$, and 123.71. Mass spectrum $(M S)$ : mass/charge $(\mathrm{m} / \mathrm{z}) ; 32,44,63,152$ molecular ion peak $(M+)$. The 2-pyridylglycine fused with admixture sodamide - sodium hydroxide-potassium hydroxide $(1: 3: 3)$ at a temperature of $220^{\circ} \mathrm{C}$ to yield Pyridylpyrrol-3-one which was oxidized to 2-(1, 3- dihydro- 3 - oxo- $2 \mathrm{H}$ - pyridylpyrr- 2- ylidene)-1, 2-dihydro$3 H$ - pyridylpyrrol-3-one. This compound sublimed at $393^{\circ} \mathrm{C}$ and showed the following spectral features: UV:(

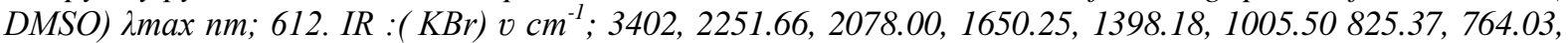

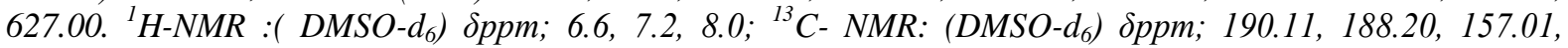
$155.21,149.60,148.11,136.02,134.50,130.0,128.94,27.53,126.31,124.30,123.91 . M S: \mathrm{m} / \mathrm{z} ; 32,77,105,181$, $264(M+)$. This compound was a dark-blue vat dye.

Keywords: 2-aminopyridine, isolable, pyridylpyrrol-3-one, spectral features, $S_{N} 2$, vat dye. 
1. Heumann, K; Ber; 27, 27653 (1894).

2. Heumann, K; Ber; 23, 3043(1890).

3. Posner, T; Beitrage Zurkenntuis Der Indigo-Gruppe VI Uber Die Einwirkung von Saure-Chloriden auf Indigo und Indigo-Derivative; Ber.Dtsch.Chem. 59, 1799-1833 (1926).

4. Von Eller,H;Stereochem De l'Indigo dans l'etat Cristallin,C.R.Hebd.Seances,Acad.Sci.239, 975-976 (1954).

5. Friedlander, P. and Bezdik, A; Monatsch 29, 375 (1908).

6. Friedlander, P; Ber.39, 1060 (1906).

7. Herz, R; US Patent 1699432, Chem. Abst. 22, 1365 (1929).

8. Hadacek, J; Publs. Sci. Univ. Masaigk Crislo 357, 259-260 (1954).

9. Joshi, D; Wuji Xuebao 20 (4), 373-380 (2004).

10. Lin, S; Synthesis 7, 548-549 (1989).

11. Mcgovern, P.E. and Michael, R.H; Royal Purple Dye: Tracing Chemical Origins of the Industry, Anal.Chem. 57, 1514A-1522A (1985)

12. Kos, C; Process for the Preparation of Indigo, US Patent 5, 686625 (1997).

13. Yamamoto, Y and Takaki, U; Aoki, S and Hara, I; Process for the Preparation of Indigo US Patent 4, 706973. (1990).

14. Benkelman, T.E; The Analytical Chemistry of Synthetic Dyes, Van Kataraman, K. Ed, John Wiley and Sons, New York 255-267 (1977).

15. Bujan, Elba I; J. of Phys. Org. Chem.19 (3), 187-195 (2006).

16. Rice, H.M; Can. J. Chem. 30, 575-580 (1952).

17. Rodriguez, O; Industrial and Engineering Chemistry Research, 46 (24) 8199-8204 (2007).

18. Azarifa, D; Heterocyclic 68 (1), 175-181 (2006).

19. Gawinecki, R; Magnetic Resonance in Chemistry 36 (11), 848-854 (1998).

20. Heumann, K; Ber. 27, 2653 (1894).

21. Ege' Seyan N; Organic Chemistry, Structure and Reactivity $4^{\text {th }}$ Ed. Houghton Mifflin Co., 833 (1999).

22. Lubs, H.A; The Chemistry of Synthetic Dyes and Pigments, Robert E. Krieger Pub. Co; 5 (1972).

23. Rys, P And Zollinger,H; Fundamentals of Chemistry and Application of Dyes, John Willey Intersci, John Willey and Sons Ltd. London, 124 (1972).

24. Bahl, B.S; Advanced Organic Chemistry, S. Chard Pub.Co, Ltd, New Delhi 1155-1156 (2007).

25. Okafor, C.O and Okoro, U.C; Three Branched Diazaphenothiazine Dyes and Pigments 9, 427-442 (1988).

\section{References}

[1] Okafor, C.O. (1973). Studies in the Heterocyclic Series viii, The First Synthesis of a Triazaphenothiazine Ring.J.Org. Chem.; vol.38, No.26.pp.4387-4390.

[2] Okafor, C.O., Steenberg, M.L. and Buckley, J.P. (1975).A New Triazaphenothiazine Ring with Tranquilizing Activity. Het.Chem. 12, p.813.

[3] Okafor, C.O. (1980).Studies in the Heterocyclic Series xvii. Anew Type of Triazaphenothiazine, J. Het.Chem., 17, p.149.

[4] Okafor, C.O. (1982).Studies in the Heterocyclic Series xvi. Open Azaphenothiazine as New Central Nervous System Depressants. Chem.Pharm

[5] Amaral, L. and Kristiansen, J.E. (2001). Phenothiazine; Potential Management of Creutzfeldt-Jacob Disease ant it's Variants. International Journal of Antimicrobial Agents. Volume 18, pp.411-417.

[6] Amaral, L.,Martins, M. and Viveiros, M. (2007).Enhanced killing of intracellular multidrug- resistant Mycobacterium tuberculosis by compounds that affect the activity of efflux pumps.Journal of antimicrobial chemotherapy.volume 59.pp.1237-1246.

[7] Barbieri,F.,Alama ,A., Tasso, B., Boido, V., bruzdo,c and Sparatore,F.(2003). Quinolizinyl Derivatives Of Imminobenzyl And Phenothiazine As Multidrug Resistance Modulators In Ovarian Cancer Cells.Invest New Drugs. Volume 21, Pp.413-420.

[8] Gupta, R.R And Kumar, M(1988).Synthesis, Properties And Reactions Of Phenothiazines,In Phenthiazines And 1,4-BenzothiazinesChemical And Biological Aspects.Ed.Gupt,Rr Elsevier,Amsterdam, Pp.1-161.

[9] Khatri,V;Sareen,V;Sharma,K;Singh,P And Sareen,S(2011).Synthesis And Biological Evaluation Of Substituted 10h-1Azaphenothiazine And Their 5-Oxide Derivative.Volume 1, Number 4.Pp.305-310.

[10] Krystain,P.Margozata,J;Beata,M;Micha,Z;Jolanta,A Andmaja,K(2010).Anticancer Activity Of Newly Synthesized Azaphenothiazines From Nci's Anticancer Screening Bank.Institute Of Pharmacology,Polish Academy Of Science,Volume 62.Pp.319-332.

[11] Mayur,Y.C;Jagadeesh,S And Thimmaiah,K.N(2006).Targetingcalmdulin In Reversing Multidrug Resistance In Cancer Cells Mini Rewiew (Rev)Medicinal Chemistry.Volume 6.Pp.1383-1389.

[12] Molnar,a; amaral,1 and molnar,j.(2003).antiplasmid effect ofpromethazine in mixed bacterial cultures.international journal of antimicrobial agents.volume 22.pp.217-222.

[13] Mosnaim,a.d; ranade,v.v.,wolf, m.e.,puente,j nad valenzuela,m.a(2006).phenothiazine molecule provides the basic chemical structure for various classes of pharmacotherapeutic agents.american journal of therapeutics.volume 13.pp.261-273.

[14] Motohashi,n. and gupta,r.r (1998).phenothiazines and 1,4-benzothiazines:chemical and biomdical aspects.elsevier,amsterdam.pp.705774.

[15] Sharma 2011 B.K. (2011).Industrial Chemistry including Chemical Engineering, $16^{\mathrm{TH}}$.Ed.Geol Publishing House Meerut p.356. 